\title{
Konut Tasarımında Etkili Olan Faktörler ve Geleneksel Mimari Yaklaşımlar: Şile'de Bir Konut Örneği
}

\author{
Hülya SOYDAŞ ÇAKIR ${ }^{1}$
}

Öz

Konut tasarımları kullanıcı intiyaçları, çevresel faktörler, coğrafi ve iklimsel veri, ekonomik ve politik koşullar gibi pek çok faktör çerçevesinde şekillenmektedir. Konutlar barınma temel gereksinimini karşılarken fonksiyonel ve estetik mekanların oluşumu ile geliştirilmektedir. Kullanıcıların yaşam biçimleri, alışkanlıkları ve tercihleri, konutun tasarlanacağı yerin çevre ve doğa ile ilişkisi tasarım kararlarında önemli unsurlar olarak karşımıza çıkmaktadır. Konut tasarımında fiziksel, psikolojik ve toplumsal açıdan farklı kullanıcı gereksinimlerinin karşılanmasına çalışılmaktadır. Bu açıdan konut tasarımında işlevin ve estetiğin kullanıcı ihtiyaçlarını göz önüne alarak oluşturulması bir denge gerektirmektedir. Konut tasarımında geleneksel mimari özelliklerin çağdaş malzeme ve teknoloji ile yeniden ele alınması ve yorumlanması bu alanda farklı örneklerin hayata geçirilmesine imkan sağlamaktadır. Bu çalışmada İstanbul'un Şile ilçesinde kullanıcıların intiyaçları ve tercihleri göz önüne alınarak yazar tarafından tasarımı ve uygulaması gerçekleştirilen bir müstakil tek aile konut örneği ele alınmaktadır. Tasarım kararlarının alınma süreci, geleneksel konut ilkelerine yaklaşımlar, çevresel ve kültürel etkileşimler çerçevesinde uygulama aşamaları ve sonuç deneyimler tartışılmaktadır. Konutun planlamasında göz önüne alınan faktörler geleneksel tasarım ilkeleri ile kurulan ilişkiler ve kullanıcı gereksinimleri beraberinde gerçekleştirilen uygulamalar aşamaları ile birlikte sunulmaktadır.

Anahtar Kelimeler: Konut, Tasarım, Kullanıcı, Geleneksel mimari, Şile

\section{House Designing Affective Factors and Traditional Architectural Approaches: An Example House in Şile}

\begin{abstract}
\footnotetext{
${ }^{1}$ Fenerbahçe Üniversitesi Mühendislik ve Mimarlık Fakültesi, İstanbul Illgili yazar/Corresponding author: hulya.soydas@fbu.edu.tr Gönderim Tarihi / Received Date: 11.03.2021 Kabul Tarihi / Accepted Date: 04.08.2021
}

House designs are formed by various factors such as user needs, environmental facts, geographical and climatic data, economical and political issues. As houses meet the basic need for shelter, they are developed by designing functional and aesthetic spaces. The life styles, habits and preferences of the users, the relation between the environment and nature and the site of the house appear as important facts in design process. By house designing, it is aimed to meet different user needs in terms of physical, psychological and social aspects. In this respect, establishing the function and aesthetics in house design by considering the needs of the user requires a balance. The reconsideration and interpretation of traditional architectural features in house design with contemporary materials and technology enables different patterns to be realized in this field. In this study, an example of a single family house is discussed that is designed and constructed by the author considering the needs and preferences of the users in Şile, a district of Istanbul. In this article, the process of making design decisions, approaches to the traditional house designing principles, construction stages 
and outcome results within the framework of environmental and cultural interactions are discussed. The factors taken into consideration in the planning of the house are presented together with the relationships established with the principles of traditional design and the application stages accomplished together with the user requirements.

Keywords: House, Design, User, Traditional architecture, Şile

\section{Giriş}

Kullanıcılar için konforlu, sağlıklı, estetik ve ekonomik konutların tasarlanması ve uygulanması amacıyla projelerin fikir aşamasından itibaren bireysel ve toplumsal açıdan çok boyutlu olarak ele alınması gerekmektedir. Konut tasarımında yerel ve kültürel verinin doğru kullanılması, çevresel ve doğal verinin düzgün işlenebilmesi, estetik ve fonksiyonel mekansal organizasyonların yapılabilmesi, maliyetlerin uygun bir çerçevede gerçekleştirilebilmesi önemli hedeflerdir. Her türlü yapının oluşturulmasında ilgili çevrenin ve kültürel dokunun tasarım kararlarından itibaren korunması ve gelecek nesillere aktarılması gerekir. Konut gibi insan yaşamında oldukça önemli bir yaşam alanının planlamasında sağlık, ekonomi, sosyal yapı gibi birçok unsur gözönünde bulundurulmaktadır. Günümüzde kaynakların artan tüketimi, çevresel ve ekolojik değişimler, aile yapısındaki dönüşümler, bilgi ve iletişim teknolojilerinin hızlı gelişimi gibi faktörler konut tasarımına bakış açılarında da değişime neden olmaktadır. Kentlerde nüfus artışı ile birlikte yaşanan gelişmeler, değişen mekan büyüklükleri, dönüşüm projeleri, giderek artan kırsala dönüş talepleri konutların biçimlenmesinde rol almaktadır. Konut tasarımında kullanıcı beklentilerinin karşılanabilmesi, kullanıcı intiyaçlarına çözüm oluşturulabilmesi tasarımın başarısı açısından önemli kriterlerdir. Tasarımda günlük işlevlerin yer aldığı, fonksiyonel, teknik anlamda sağlam ve güvenilir aynı zamanda estetik ve sağlıklı mekanların oluşturulması beklenir.

Değişen yaşam koşullarına uyum sağlayan konut tasarımları, geleneksel mimari tasarım yaklaşımlarından ve kullanıcıların aile yaşantılarından, sosyal ve kültürel yapılarından beslenebilmektedir. Konutun ve çevresinin yaşam kalitesiyle ilişkilendirilmesinin; kullanıcı karakteristikleri, konutun bulunduğu çevre özellikleri ve erişilebilirlik başıkları altında incelendiği bulgulanmaktadır. Kullanıcıların yaşları, eğitim durumları, yaşam döngüleri gibi özelliklerinin, konut yakın çevresinin temizlik, bakım gibi fiziksel özelliklerinin, kentsel hizmetler gibi değişkenlerin, erişilebilirlik açısından ise konutun konumu, sosyal donatılara, ulaşım akslarına erişimi gibi unsurlar memnuniyet açısından ele alınmaktadır (Salihoğlu ve Türkoğlu, 2019, s. 207). Cumhuriyet Dönemi konut mimarisinde plan tiplerinde ve mekan fonksiyonlarında geleneksel Türk Mimarisi özelliklerinin etkili olduğu ve Geleneksel Türk Konut Mimarlığının günümüzdeki konutlar için önemli bir basamak oluşturduğu görülmektedir (Uzun ve Topal, 2019, s.9). Bu çalışmada konut tasarımında yüzyıllardır benimsenen ilkelerin ve tasarım prensiplerinin günümüzde çağdaş yaklaşımlar ile yorumlanmasının tasarıma sağladığı katkılar ele alınmakta, İstanbul'un Şile ilçesinde yazar tarafından konut olarak tasarımı ve uygulaması gerçekleştirilen Aydın Ailesi Evi üzerinde örnekleri gösterilmektedir. Konut tasarımını şekillendiren çevresel, ekonomik, kültürel, yasal, teknik ve estetik unsurların analizi yapılarak tasarım yaklaşımları, kullanıcı deneyimlerinin sonuçları ile birlikte ele alınmaktadır.

\section{Yaşam ve Yerleşim Açısından Şile İlçesi}

Şile ilçesinin, İstanbul şehir merkezi olan yakınlığı ve çevreyolu bağlantılarının ulaşım açısından etkileri ile birlikte yerleşim seçeneklerinde tercih edilirliği artış göstermektedir. Karadeniz kıyısındaki sahil uzunluğu, karakteristik kumsalları, geniş 
orman alanlarına ve mesire yerlerine sahip olması ilçeyi günübirlik/sezonluk turistik ziyaretler ve ikinci konut/hafta sonu evi gibi yapılaşma aktiviteleri açısından tercih edilir duruma getirmiştir. Bir dönem iş bulma olanaklarının giderek azalması, tarım faaliyetlerinin düşmesi yerel ilçe nüfusunun kırsal alanlardan metropole doğru kaymasına neden olmuştur. Ancak uzun yıllar sayfiye merkezi olarak yaz aylarında günübirlik seyahatlerin popüler noktası olan ilçe, artık yaz-kış kulllanılabilen ve şehir yaşamından kısa bir mesafede ve günlük ortalama ulaşım süreleri dahilinde erişim sağlanabilecek bir yerleşim merkezi haline gelmektedir. İş ve eğitim olanaklarının ilçede çeşitlenmesi, şehir hayatından ve kalabalıktan uzak, doğa ile ilişkili yerleşim seçeneklerin oluşturulabilmesi ilçenin dikkat çekmesini sağlamaktadır.

Şile yerleşimi Kuzey Anadolu fay hattına $40 \mathrm{~km}$. uzaklıkta yer almaktadır. Bölge 2. derece deprem kuşağı olarak değerlendirilmektedir. İlçenin topoğrafik özellik açısından düz bir rölyef üzerinde yer aldığı görülmektedir. Kısa mesafelerde yükselti farkının az olması beraberinde bölgede farklı strüktürler yer almamaktadır (Şentürk ve Biricik, 2016). Bölge coğrafi olarak Akdeniz ve Karadeniz iklim özellikleri arasında bir geçiş iklimi özelliği taşımaktadır. Marmara ikliminin yer aldığı saha üzerinde yaz kuraklığı azdır. Bölge normal miktarda kar yağışı almaktadır ancak sık don olayı gözlemlenmektedir. Soğuk ve yağışlar etkin olup, bulutluluk ve nisbi nemlilik fazladır (Ertek ve Evren, 2004, s.109). Bölgenin özellikle batı bölümü endüstriyel ham madde stoğu açısından zengin olup; kil, kaolin, çimento hammaddesi olarak kullanılan puzolan ve silis kumu maden havzaları yer almaktadır (Ertek, Kozak ve Evren, 1998, s.283). Ömerli ile Şile arasındaki bölge seramik kili ve silis kumu açısından Türkiye'nin en önemli seramik ve döküm sanayi ham madde bölgesi durumundadır. Bölgede istifin en altındaki kaba taneli kum malzemesi yıkanarak inşaat kumu olarak İstanbul'a sevk edilmektedir. Şile-Kirazlıyataktepe-Avcıkoru-Üvezli'de linyit kömürü, Şile-Ağva'da dolomit sahaları bulunmaktadır (URL-1). Bölgede aktif olarak işletilen maden ocakları; özellikle kayın, meşe, karaçam gibi ağaç türlerinin yer aldığı orman alanlarında çevre açısından ve ham madde sevkiyatlarının oluşturduğu trafik yoğunluğu açısından dikkatli olarak denetlenme zorunluluğunu beraberinde getirmektedir.

İlk çağlardan itibaren yerleşim alanı olarak tespit edilen ilçe ilerleyen yüz yıllarda farklı toplumların barındığı ve yaşadığı bir bölge olmayı sürdürmüştür. Şile kıyılarının da dahil olduğu Karadeniz kıyı şeridi boyunca uzanan kumullarda Orta Paleolitik dönemden M.Ö. 100 bin yıllarından, Mezolitik dönemden M.Ö.10 bin yıllara ait çok sayıda malzeme ve buluntu tespit edilmiştir (Özdoğan, 2016, s.19). Şile tarih boyunca Hitit, Frig, Lidya, Pers, Bithynia, Roma, Bizans ve Selçuklu gibi medeniyetlerin hakimiyetleri altında kalmıştır (Temir, 2010, s.16-23). İlçe, Cumhuriyet öncesinde yaklaşık 500 yıl süresince Osmanlı yönetiminde kaldıktan sonra 1. Dünya Savaşı ile geçtiği İngilizlerin denetiminden 1922 yılında çıkarılmıştır (Ertek, Kozak ve Evren, 1998, s.176). Kurtuluş Savaşı sonrasında sağlam kalan Bizans dönemi eser sayısı çok azdır. Şile'de Osmanlı dönemini teslim eden ahşap ve kargir konutlar yer almaktadır. Bu konutlar kendilerine özgü sade tarzdadır (Teker,1992, s.21-22).

\section{Geleneksel Konut Tasarımları Ve Bölgedeki Uygulamalar}

Geleneksel konut örnekleri ilçede genellikle iki katlıdır. Giriş katları günlük oturma, mutfak alanı ve tuvalet gibi genel ihtiyaçlara üst katlar ise yatma/uyuma intiyaçlarına cevap verecek şekilde oluşturulmaktadır. Mekanlar arası bağlantılar için sofa kullanılmaktadır. Günlük oturma odası sokağı ve girişi en iyi şekilde görebilecek biçimde düzenlenmektedir (Göktaş, 1992, s.22-23). Sofa, geleneksel konutlarda odaların önünde hizmet alanı veya odalar arasında ortak kullanım alanı olarak yer alır (Küçükerman, 1991, s.59). Bu konutlarda pencereler genellikle giyotin tarz sürmelidir 
ve bire iki oranındadır. Pencereler hem oturan kişinin ve hem de ayaktaki kişinin görüşünü kesmeyecek şekilde tasarlanır (Bektaş, 2019, s.127). Şile'de yer alan evlerde payanda örneklerinin tümü ahşaptır. Bu payandalar çıkmanın her iki kenarında ve ortada üçlü gruplar halinde veya dar cepheli ve tek yönlü çıkmalarda iki kenarda yer almaktadır. Payandalar yaklaşık 40-50 cm. çıkmaları destekleyecek şekilde ve çoğunlukla 45 derecelik açı ile oluşturulan hafif profillerle biçimlendirilmiş yapı elemanları olarak karşımıza çıkmaktadır. Payandalar çoğunlukla estetik görünüm kazandırmak amacıyla kullanılmakta ancak taşıyıcı özelliklerini de sıklıkla korumaktadır. Evlerde üst katın konsol döşeme kirişleri taşıyıcı unsurlar olmaktadır (Göktaş, 1992, s.50).

Geleneksel Türk evleri Sedad Hakkı Eldem (1954) tarafından dört esas plan tipinde tanımlanmaktadır (Tablo 1). Bu plan tiplerinin hiçbirine uymayan ev örneklerin de bulunduğunu ancak bunların istisnai örnekler olduğunu belirtilmektedir (Eldem, 1954, s. 24).

Tablo 1. Gelişim derecesine göre örnek Türk evi plan tipleri (Eldem, 1954)

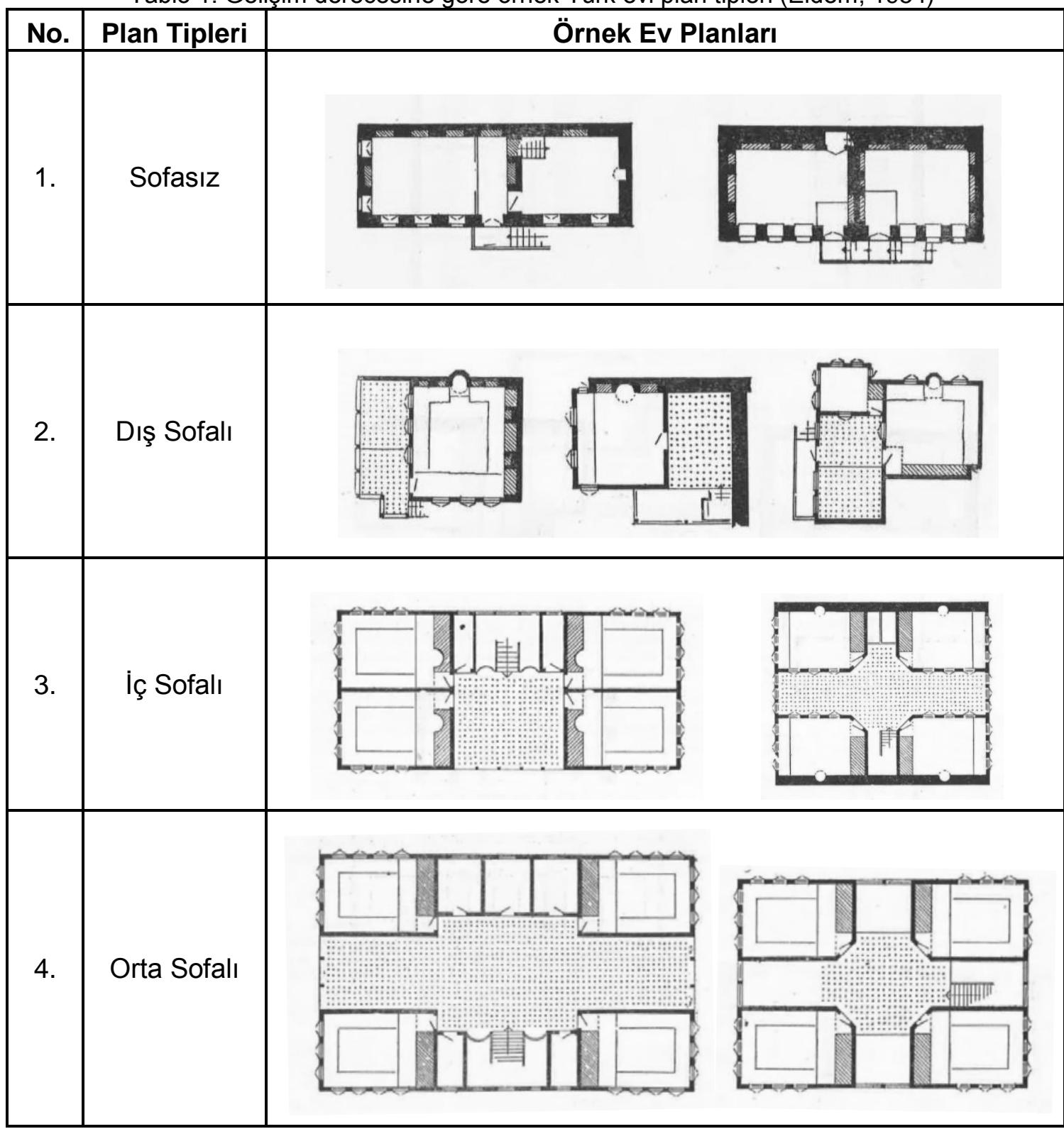


Şile geleneksel plan örneklerinde çıkmalar; sofa aksını simetri ekseni olacak biçimde ele alınarak, iki yandaki odaların çoğunlukla kendi doğrultularında iki yandan dışarıya taşma yapması şeklindedir (Göktaş, 1992, s.48). Bölgede yapılan kapsamlı bir dokümantasyon çalışmasında, geleneksel yapıların çoğunun orta eksene göre simetrik plan ve cepheye sahip oldukları tespit edilmiştir. Elde edilen veriye göre plan tipleri için sofalar dikkate alınarak Tablo 2'de yer alan yeni bir sınıflandırma yapılmıştır.

Tablo 2: Şile konut örneklerinde plan tipleri (Cura ve Eyüpgiller, 2019, s.365)

\begin{tabular}{|l|l|}
\hline Konut Tipi & Sofa Türü \\
\hline \multirow{3}{*}{ Tek Evler } & Dış Sofalı (Hol) \\
\cline { 2 - 2 } & İç Sofalı \\
\hline \multirow{2}{*}{ İkiz Evler } & Dış Sofalı \\
\cline { 2 - 2 } & İç Sofalı \\
\hline
\end{tabular}

Şile konutları üzerinde bölgede yapılan bir araştırmada rölöveleri alınan evlerden yola çıkarak başlıca plan tipleri oluşturulmuştur (Teker,1992, s.31). Bu plan tiplerinden iç sofalı çözümler Şekil 1'de görülmektedir. Konutun üst katında sofa ortak mekan olarak yer almakta, banyo ve odalar bu mekana açılmaktadır.

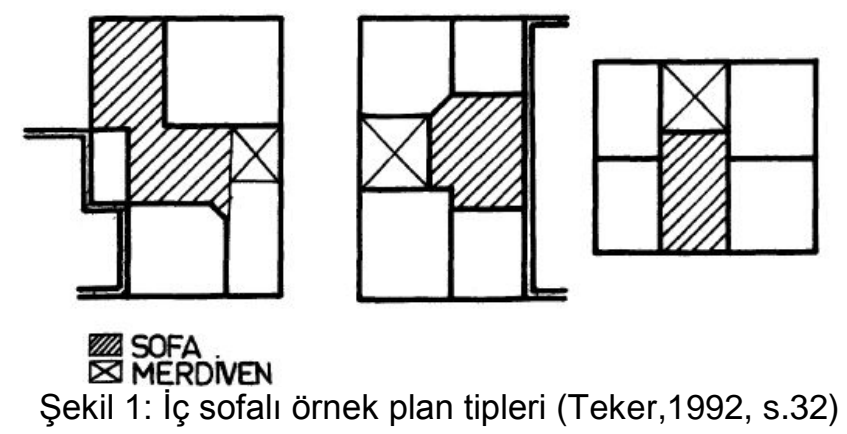

Kuban tarafından tarif edildiği gibi "Yapı eylemi, istenen herhangi bir amaca uygun bir biçimi ve bu biçimi ayakta tutacak strüktürü, amacına uygun bir malzeme ile, yapım tekniğinin olanakları içinde gerçekleştirmektir". Yapının bulunduğu toplum kültürünün kendine özgü nitelikleri, yapının biçimlenmesinde belirleyici önemli faktörlerdir (Kuban,1992, s.13-20). Konut planları ve intiyaç programları bulundukları toplumla yakından ilişkilidir. Sedad Hakkı Eldem'in, konut projelerinde program ve yapım teknikleri farklı olmak üzere, geleneksel Türk sivil mimarlığının karakterini günün koşullarına göre uyguladığı görülmektedir (Baydar ve Gerçek, 1982, s.7). Türk evi, fonksiyonel olmak üzere plan/strüktür oluşumunda çevre ve iklim koşullarını gözönüne alarak biçimlenmektedir. Bektaş (2019), Türk evinin oluşum ilkelerini bazı başlıklar altında sınıflandırmaktadır. Bu ilkeler hep çağdaş kalarak; üslup, dönem, varlık/yokluk gibi koşullardan etkilenmeyerek, büyük tavizler verilmeden uygulanmışlardır (Tablo 3). 
Tablo 3. Türk evi oluşumunda etkili olan ilkeler (Bektaş, 2019, s.33-42)

\begin{tabular}{|c|c|}
\hline İlkeler & İlke özellikleri \\
\hline $\begin{array}{l}\text { Yaşama, doğaya, çevre koşullarına } \\
\text { uygunluk }\end{array}$ & $\begin{array}{l}\text { İklime göre çözüm } \\
\text { Çevreye saygılı tasarım } \\
\text { Diğer canlı varlıklarla denge içinde olunması } \\
\text { Sıcaklık, aydınlık gibi doğal dengeler kurulması }\end{array}$ \\
\hline Gerçekçilik, akılcılık & $\begin{array}{l}\text { Erişilebilen olanaklarla yapım } \\
\text { Gösterişten uzak tasarım } \\
\text { Yöreden ve kolay sağlanan türde araç-gereç } \\
\text { Zorlama olmayan yapım tekniği } \\
\text { Akıllı, yalın, az ile çok çözüm amaçlı üretim }\end{array}$ \\
\hline İçten dışa çözüm & $\begin{array}{l}\text { Önce işlevin çözümlenmesi } \\
\text { İç işlevin ve estetiğin dışa yansıması }\end{array}$ \\
\hline İç-Dış uyumu & $\begin{array}{l}\text { İçtenlik, yalınlık, olduğu gibi görünme özellikleri } \\
\text { ile iç-dış uyumu } \\
\text { Dışarıdan içerinin okunabilmesi }\end{array}$ \\
\hline Tutumsallık & $\begin{array}{l}\text { Kullanımda tutumluluk } \\
\text { İyi belirlenmiş ve tasarlanmış ortak kullanım } \\
\text { mekanları } \\
\text { Gösteriş ve harcamadan uzak tasarım } \\
\text { Tümü kullanılan, atıl kalmayan mekanlar } \\
\text { Yağmur, ısı gibi unsurlardan yararlanma }\end{array}$ \\
\hline Yapım yöntemlerinde kolaylık & $\begin{array}{l}\text { En azla en akıllı çözüm } \\
\text { Gerekmeyen hiçbir tekniğin kullanılmaması }\end{array}$ \\
\hline Ölçülerin insan vücudundan çıkması & $\begin{array}{l}\text { Evde yer alan tüm ölçülerin tasarımcının ve } \\
\text { kullanıcının ölçülerinden şekillenmesi } \\
\text { Modulor/Altın oran sistemlerinin kullanımı }\end{array}$ \\
\hline Çevre gereçlerini kullanma & $\begin{array}{l}\text { En yakın çevrenin gerecinin kullanılması } \\
\text { Çevreye uyum ilkesinin desteklenmesi }\end{array}$ \\
\hline Esneklik & $\begin{array}{l}\text { Büyümeye imkan verecek biçimde tasarımın } \\
\text { İhtiyaç durumunda bölünebilme olanağı }\end{array}$ \\
\hline İnsan faktörü & $\begin{array}{l}\text { İnsancıl ortamın oluşturulması } \\
\text { Evin yuva olarak değer taşıması }\end{array}$ \\
\hline
\end{tabular}

Konut tasarımda bugün de geçerli olmak üzere kullanıcı memnuniyetinin, çevreye uyumun ve saygılı yaklaşımın kurgulanmasında bu ilkelerden etkin biçimde yararlanılması fayda sağlamaktadır. Günümüzde sürdürülebilirlik, esneklik, ekonomiklik gibi birçok kavramın bu ilkeler ile ilişkili olduğu görülmektedir. Türk evinin oluşum ilkeleri bugün için de tasarımcılar açısından kılavuz niteliği taşımaktadır. Konut için çıkış noktası olan insanı ön plana alan aynı zamanda çevre, doğa, kaynaklar açısından duyarlı ve özenli tercihleri barındıran bu yaklaşımlar geçerliliklerini sürdürmektedir.

\section{4.Örnek Konut Mimarisi ve Tasarım Yaklaşımları}

Tasarımı ve uygulaması gerçekleştirilen yapı Şile Ahmetli Köyü mevkiinde müstakil konutların yer aldığı bir alanda tek aile evi olarak tasarlanmıştır. Konut, 3 çocuklu 
serbest çalışan bir çifte ait olarak her mevsim kullanılmak üzere inşa edilmiştir. Konut arazisi İstanbul iline $60 \mathrm{~km}$. uzaklıkta araçla yaklaşık 50 dakikalık ulaşım mesafesindedir. Konut Şile ilçe merkezine yaklaşık $4 \mathrm{~km}$. uzaklıktadır. Merkez çarşıya araçla 10 dakikada, yaya olarak yaklaşık 40 dakikada ulaşılabilmektedir. Mevcut alan 1/1000 ölçekli Şile Belediyesi Ahmetli Köyü Uygulama İmar planı kapsamında olup, ayrık nizamlı zemin+1 normal kat yüksekliğinde yapılaşma için uygundur. Aynı imar planına göre bina yüksekliği $h=6,50 \mathrm{~m}$.'dir. Konut arazisinin güneydoğusunda Şile ilçe merkezi, kuzeydoğusunda Karadeniz yer almaktadır. Konutun konumu, deniz ve ilçe yerleşimi ile olan ilişkisi Şekil 2'de kırmızı işaretleme ile gösterilmektedir.

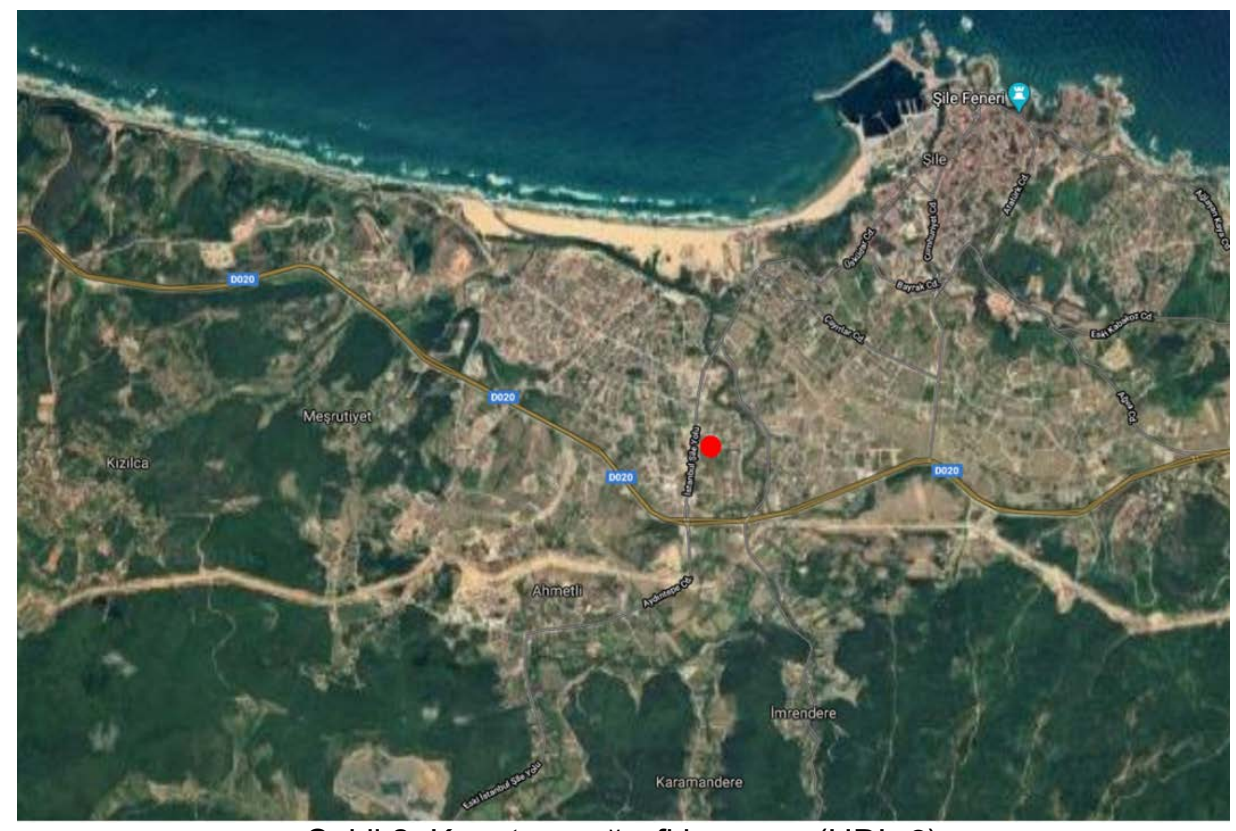

Şekil 2: Konutun coğrafi konumu (URL-2)

Mevcut yapılaşma bölgesinde \%20'lik taban alan kullanım katsayısı bahçe ve açık alanda geniş mekanlara olanak sağlamaktadır. Konutun brüt inşaat alanı yaklaşık 214 $\mathrm{m}^{2}$ 'dir. Şile ilçesi akarsu çeşitliliğine sahip bir bölgededir. Türknil Nehri, Kabakoz Deresi, Göksu Deresi ve Ağva Deresi bölgenin en önemli akarsularıdır. Uygulaması yapılan konut, kaynağını iç kesimlerden alarak Karadeniz'e dökülen Türknil Nehri yakınındadır. Bu nehrin yatağında her mevsim su bulunmaktadır (Sezer, 2006). Bölgesel topografik eğim Kuzey-Güney yönlü olmak üzere $5^{\circ}$ dir. Kuzey rüzgarları bölgede egemendir (Fotoğraf 1, Fotoğraf 2).

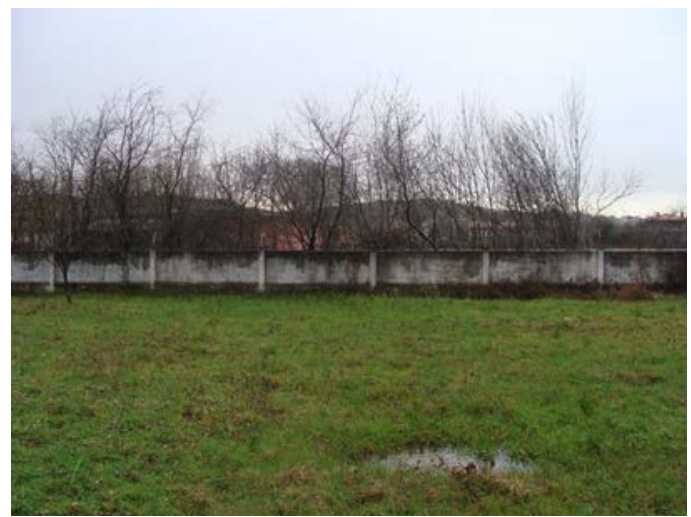

Fotoğraf 1: Konut doğal arazisi (Hülya Soydaş Çakır, 2009)

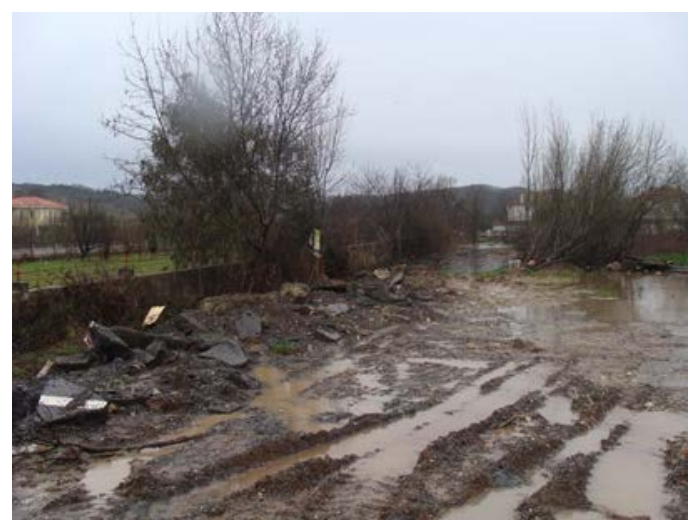

Fotoğraf 2: Uygulama öncesi arazi durumu (Hülya Soydaş Çakır, 2009) 
Konutun yer aldığı alanda 7269 sayılı kanun kapsamına giren heyelan, su baskını, kaya düşmesi, çığ gibi doğal afet riski belirlenmemiştir. Yapılan zemin etüdü sonucunda yeraltı suyuna yaklaşık 2.0 metrede rastlanmıştır. Dolayısıyla sızıntı suları ve yüzeysel sulara karşı temel ve çevre drenajı sağlanmıştır. Yapı için temel derinliği bina oturum alanı içerisinde dolgu zonu dikkate alınarak 0,60 m. olarak belirlenmiştir. Yapı temelleri Belgrad formasyonuna ait çakıllı kumlu killi ve siltli birimler üzerine oturmaktadır. Yeraltı su seviyesi gözönüne alındığında olası sıvılaşmayı engellemek amacıyla zeminin hafredilerek $200 \mathrm{~cm}$. derinliğinde ıslah edilmiş zemin elde edilmesine karar verilmiştir. Bu derinlik için Şile taş madenlerinden getirtilen irili ufaşı taşlar ve çakıl kullanılarak gerekli sıkıştırma ve zemin iyileştirmesi gerçekleştirilmiştir (Fotoğraf 3 , Fotoğraf 4).

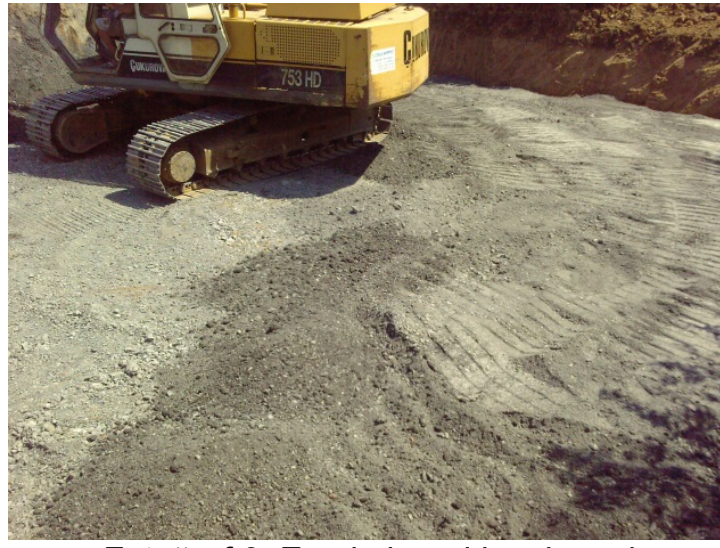

Fotoğraf 3: Zemin hazırlık çalışmaları (Hülya Soydaş Çakır, 2009)

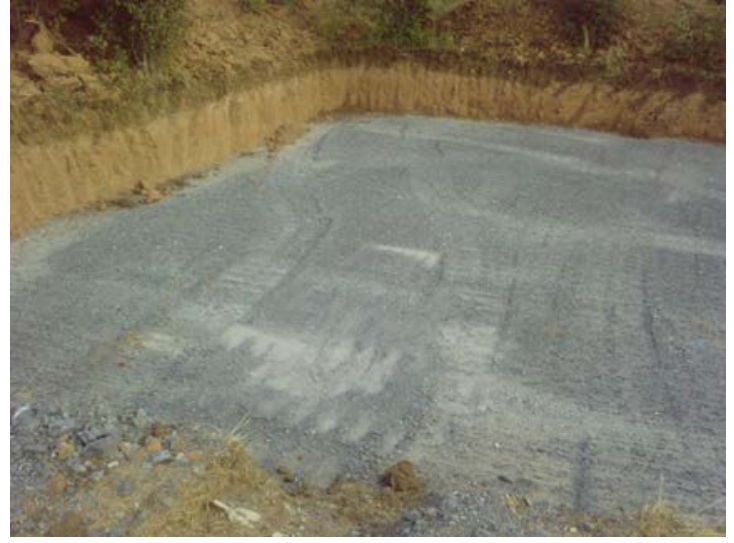

Fotoğraf 4: Temel inşaatı öncesi zemin (Hülya Soydaş Çakır, 2009)

Bölgenin özellikle deprem riski gözönüne alınarak yapısal planlamada sağlam, kalıcı ve erişim olanakları yüksek güncel yapı malzemelerinden ve yöntemlerinden yararlanılmıştır. Uzun yıllar boyunca deprem, rüzgar, nem, don, zemin su seviyesinin yükselmesi gibi karşılaşılabilecek sorunlara karşı betonarme karkas yapı tekniği tercih edilmiştir. Temel imalatı $50 \mathrm{~cm}$. yüksekliğinde radye temel tipinde gerçekleştirilmiştir. Isı ve ses yalıtımı amacıyla konutta gazbeton tuğla ve asmolen döşeme tipi tercih edilmiştir. Konutun inşaasında C30 beton sınıfı ve S420 betonarme çeliği kullanılmıştır (Fotoğraf 5).

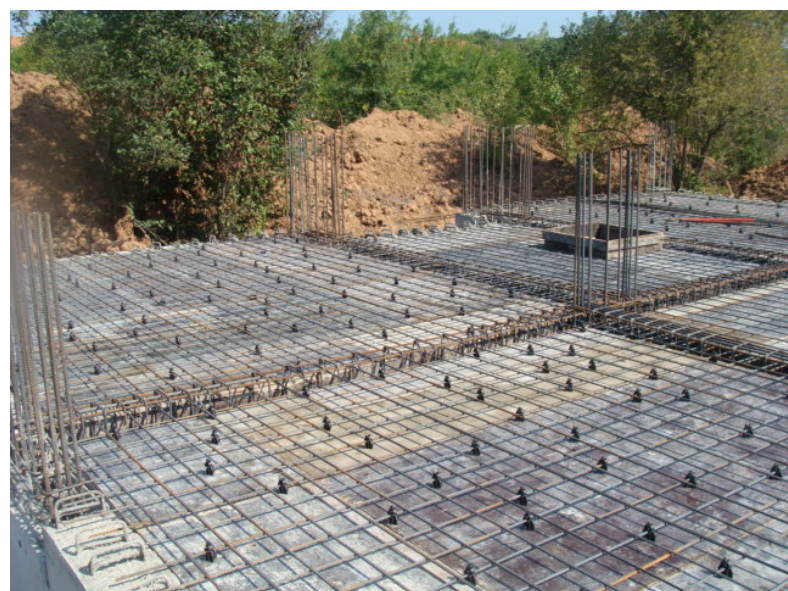

Fotoğraf 5: Zemin kat döşemesi betonarme imalat (Hülya Soydaş Çakır, 2009) 
Geleneksel mimari tasarım unsurlarının projede yer alması konut sahipleri ile ortak görüş sonucunda kararlaştırılmıştır. Konut tasarımında doğal çevreye ve iklime uyum ön plana alınmıştır. Birçok imalatta yerel malzemeden ve işçilikten yararlanılmıştır. Geleneksel mimarlıkta ağırlıklı olarak taş, tuğla, ahşap gibi doğal malzemeler kullanılmaktadır. Kuzey Anadolu konutlarında ahşap malzemeden kolay işlenebilmesi ve detay çözümlerindeki çeşitliliği ile yararlanılırken, taş malzeme bahçe, avlu ve zemin kat duvarlarında yaygın olarak uygulanmaktadır (Akdemir ve Korkmaz, 2010, s.130). Nitelikli malzeme, işçilik ve detay kullanımı tüm yapıların bozulmadan uzun yıllar sağlam kalabilmelerinin en önemli faktörlerindendir. Yanlış verilen kararlarda ilk tasarım hatalarının giderilmesi çok zor olmakta ve sürekli onarım gerektiren süreçleri doğurabilmektedir (Ahunbay,1996, s.42-45). Tasarımı ve uygulaması gerçekleştirilen konutta malzemelerde ve işçiliklerde kaliteli aynı zamanda ekonomik tercihlerin yapılmasına özen gösterilmiştir.

Arazi verisi ve mevcut imar durumu göz önüne alınarak konut arsanın doğu cephesi kenarına yaklaştırılarak yerleştirilmiştir. Arsaya ana araç ve yaya girişi batı cephesinden, konut girişi ise güney cephesinden sağlanmıştır (Fotoğraf 6). Bahçe girişinde iki aracın rahatlıkla park etmesine imkan veren doğal taş kaplamalı üstü açık otopark alanı tasarlanmıştır (Fotoğraf 7).

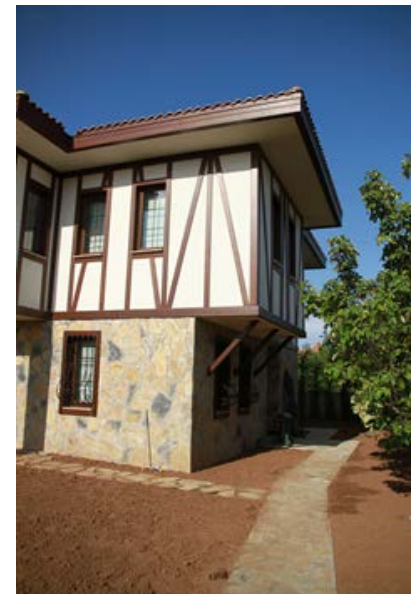

Fotoğraf 6: Konut ve yaya giriş yolları (Hülya Soydaş Çakır, 2010)

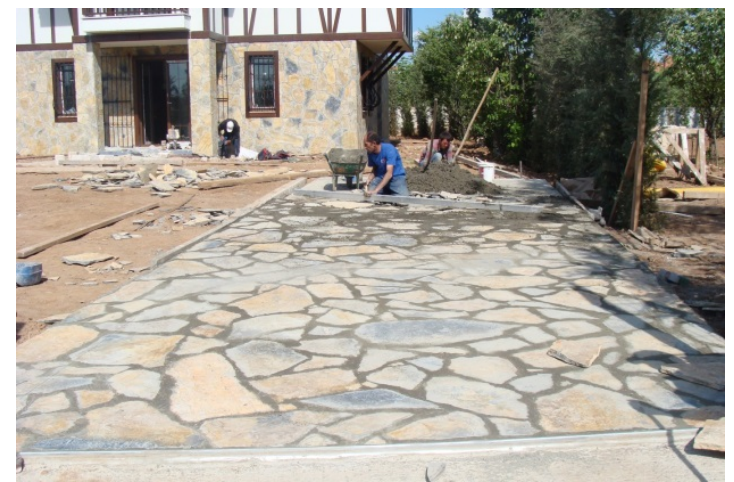

Fotoğraf 7: Doğal taş kaplamalı araç girişi (Hülya Soydaş Çakır, 2010)

Tek aile konutları kullanıcılarının konut çevresi ile ilgili memnuniyetlerinde, açık ve yeşil alan faktörü ön sırada yer almaktadır (Berköz, 2008, s.121). Projede konut sakinlerinin yeşil alana olan intiyaçları ve özel ilgileri tasarım kararlarında önemli rol almıştır. Konut arazisinin bulunduğu Şile ilçesi farklı coğrafik ve iklimsel mozaiğe sahip olmasıyla çeşitlilik içeren bir floraya ev sahipliği yapmaktadır. Bölgeye uygun ağaç türleri Gymnospermae üyeleri, meşe, gürgen, kayın ve kestane olarak sayılabilmektedir (Sezer, 2006, s. 108-109). Bölgenin çok çeşitli meyve ağaçlarının yetişmesine imkan veren iklimi gözönüne alınarak proje alanında nar, armut ve incir ağaçları dikilmiştir. Arazide mevcut durumdaki ıhlamur, ayva, erik ve fındık ağaçları ise korunmuştur. Konut sahiplerinin isteği üzerine ön bahçede ve orta aksta bir manolya ağacı ve ön bahçe duvarında bir salkım söğüt ağacı yerleştirilmiştir. Konutun bahçe sınırları ön ve arka sınırda $150 \mathrm{~cm}$. yüksekliğinde duvar ile yükseltilmiştir. Konut bahçesinin ön, arka ve komşu parsel sınırlarında $50 \mathrm{~cm}$. ara ile leylandi ve limon servi yerleşimi yapılarak, bahçe sınırlarında doğal yeşil sınır elde edilmiştir (Fotoğraf 8). 


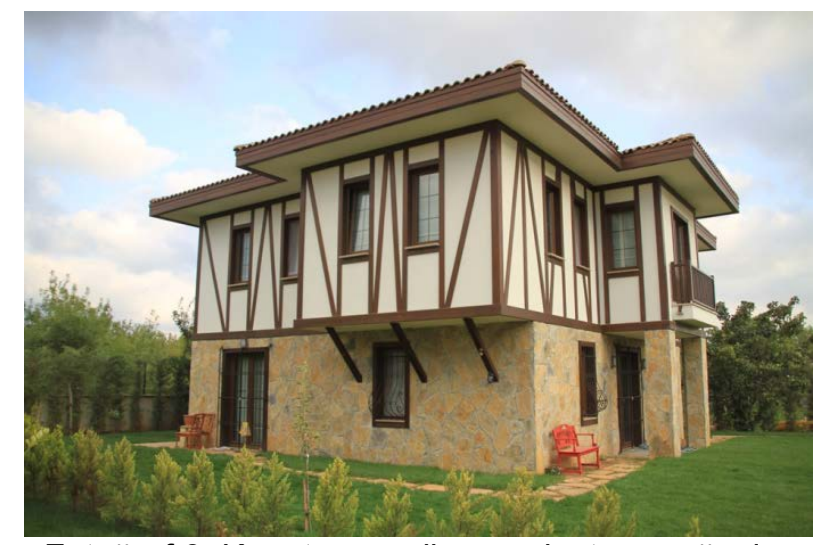

Fotoğraf 8: Konut ve yeşil sınır oluşturan ağaçlar (Hülya Soydaş Çakır, 2010)

Geleneksel evlerde zemin katın bahçeyle ilişkisi yer döşemesinin sürekliliği ile bahçeden içeri girişteki sürekliliği sağlamaktadır. Zemin kat ve üst kat arasındaki geçirgenlik ise merdivenin tasarımı, yönü ve iki kat arasındaki ilişkinin kullanıcı hareketleriyle bütünleşmesiyle oluşmaktadır (Yürekli ve Yürekli, 2007, s. 46). Tasarlanan konutun zemin katında Şekil 3'de yer aldığı şekilde 5 no.lu salon ve 6 no.lu mutfak mekanları bahçe ile bağlantılıdır. Konutun güney cephesindeki 3 no.lu ana giriş kapısı holünde bir konuk odası yer almaktadır. Gerektiğinde salon ile bu giriş holü arasındaki kapı kapalı duruma getirilerek holde yer alan 2 no.lu banyo hacmi ve 4 no.lu konuk odası ayrı yaşam/konaklama birimi olarak kullanılabilmektedir. Bu durumlarda aile bireyleri konut çıkışı olarak salonda yer alan çift kanatı bahçe kapısını kullanarak 7 no.lu terasa ve oradan bahçeye ulaşmaktadır. Geleneksel konutun esneklik yaklaşımından bu çerçevede yararlanılmaktadır. Teras, konutun 1. kat sofa cumbasının altında yer alacak şekilde korunaklı bir tasarıma sahiptir. Bu geçiş mekanı ile kot farkı oluşturulmadan zemin kat ile bahçe arasındaki süreklilik sağlanmaktadır.

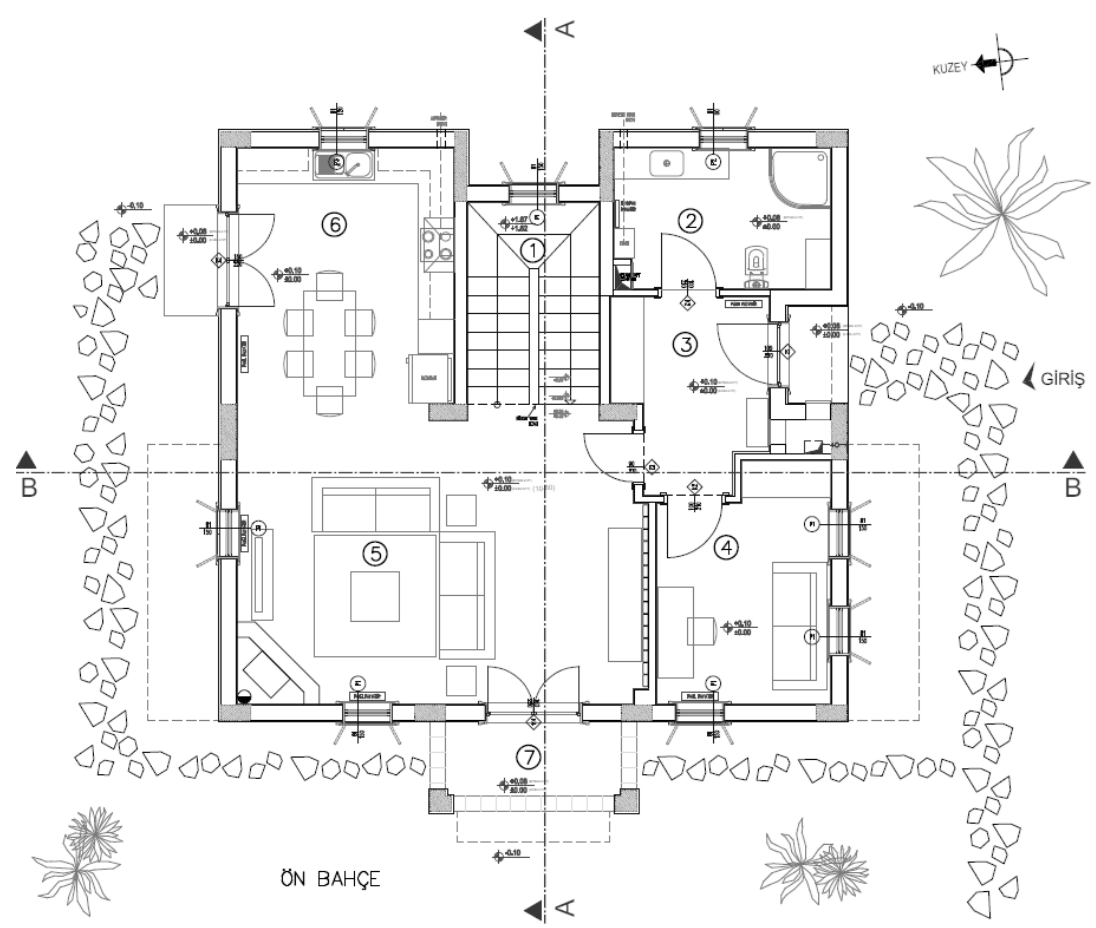

Şekil 3: Zemin Kat Planı (Çizen: Hülya Soydaş Çakır ve Burak Çakır) 
Konut içerisinde salonda yer alan ve kış aylarında ısınmayı önemli ölçüde destekleyen köşe tipi bir şömine tercih edilmiştir. Duvarlarda beyaz düz renk iç cephe boyası uygulanmış, mobilyalar sade renk ve modellerde seçilmiştir (Fotoğraf 9).

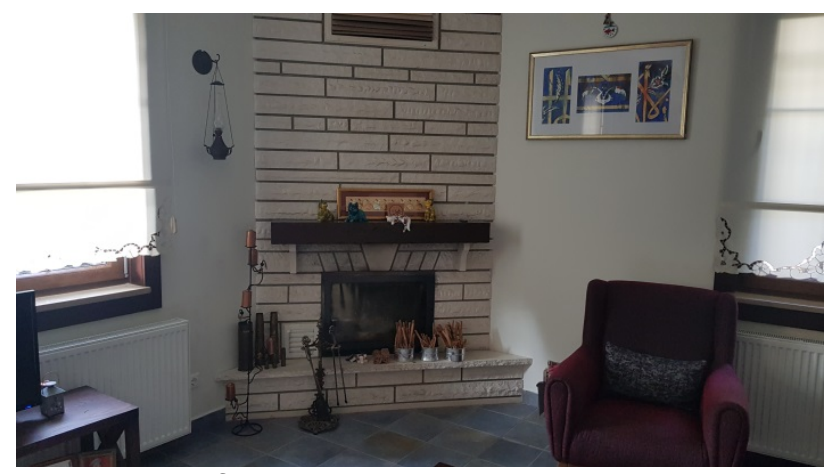

Fotoğraf 9: Zemin kat salon oturma köşesi

(Hülya Soydaş Çakır, 2020)

Geleneksel konut plan tiplerinde oda ve sofa iki temel unsur olarak karşımıza çıkmaktadır (Köse, 2005, s.184). Konutun 1. katı iç sofalı olarak; Şekil 4'deki planda yer aldığı biçimde 2 no.lu bir banyo hacmi, 3 no.lu mekan olarak bir çamaşır odası ve 4,6 ve 7 no.lu üç adet yatak odası yer alacak şekilde tasarlanmıştır. Konutun üst katında bahçeye bakan yatak odalarında tek yönlü çıkmalar bulunmaktadır. Ailenin özellikle yaz mevsimi dışında pratik olarak üst katta biraraya gelebileceği ve sohbet edebileceği şekilde tasarlanan sofa, amacına uygun olarak bir buluşma ve paylaşım alanı oluşturmaktadır. Özellikle kış günlerinde ve bahçe kullanımının uygun olmadığı yağışlı havalarda konut sakinlerinin kitap okumak ve dinlenmek amacıyla bulundukları sofa konuttaki farklı yaş aralığındaki aile bireyleri tarafından atıl olmasına izin verilmeden kullanılan bir mekan halini almıştır.

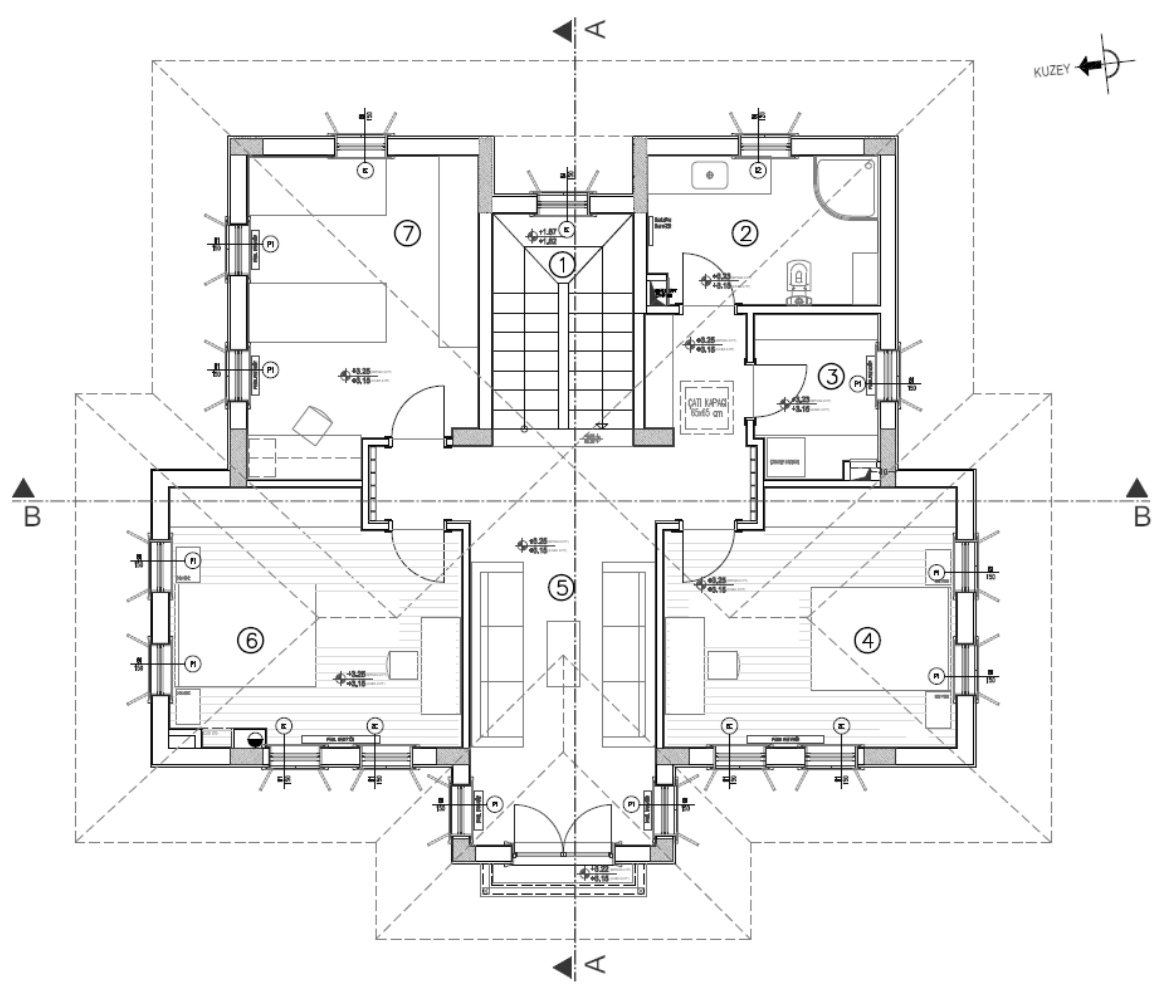

Şekil 4: 1. Kat Planı (Çizen: Hülya Soydaş Çakır ve Burak Çakır) 
5 no.lu sofa mekanı $14,30 \mathrm{~m}^{2}$ büyüklüğündedir ve bazı geleneksel konut örneklerinde görüldüğü şekilde cumbalıdır. Cumbanın yan cephelerinde birer adet pencere, ön cephesinde ise havalandırma ve bahçe manzarasına erişim amacıyla döşemeye kadar inen boy pencereler tasarlanmıştır. Sofa tefrişinde karşılıklı iki oturma grubu yer almaktadır (Fotoğraf 10, Fotoğraf 11). Mekanın zemin döşemesinde şap betonu sonrasında $30 \times 30 \mathrm{~mm}$. ebatlarında çam kadron uygulanıp, aralarına sert polistren köpük yalıtım levhası yerleştirildikten sonra doğal çam yer döşeme kaplaması (rabıta) yapılmıştır. Rabıta, geleneksel Türk evinde kullanılan bir döşeme kaplama tekniğidir. Parkeden daha geniş ve uzun ahşap döşeme kaplaması olarak tanımlanır (Hasol, 1993, s. 374).

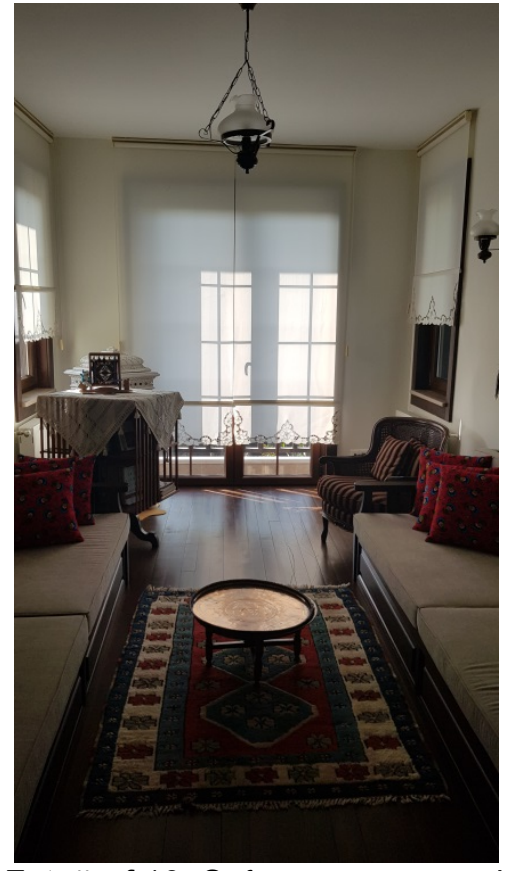

Fotoğraf 10: Sofa ve oturma grubu

(Hülya Soydaş Çakır, 2020)

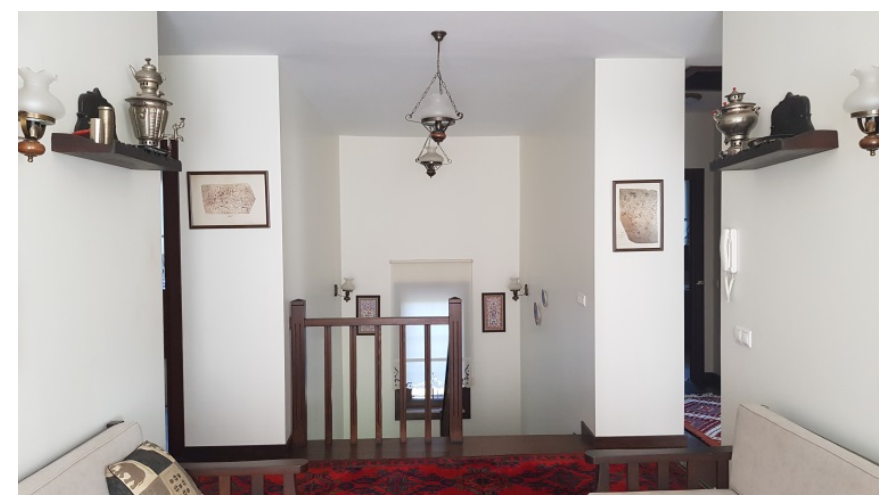

Fotoğraf 11: Sofa ve merdiven holü ilişkisi (Hülya Soydaş Çakır, 2020)

Yatak odaları ev sahiplerinin ve gelen konukların odaları rahatça kullanabilmeleri amacıyla geniş ve doğal ışıktan yararlanabilecek şekilde tasarlanmıştır. Bu odalarda da geleneksel ahşap döşeme kaplama malzemesi tercih edilmiştir. Zemin katı üst kata bağlayan ana merdiven masif ahşapla kaplanmıştır (Fotoğraf 12). 


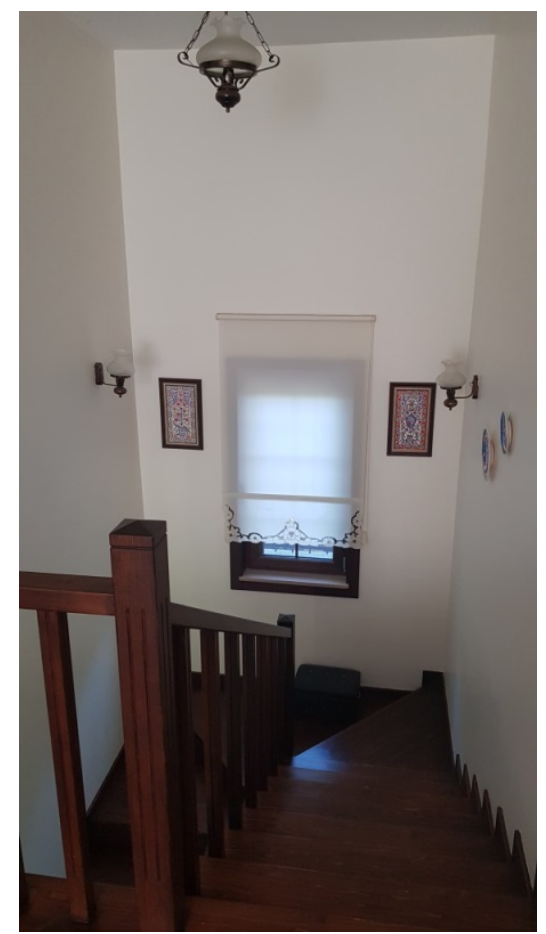

Fotoğraf 12: Konut merdiveni (Hülya Soydaş Çakır, 2020)

Türk evleri ahşap çatıların karakteristik özelliği basit olmalarıdır. Karmaşık çatı çözümlerine gidilmeden beşik, kırma ya da ikisinin birarada kullanıldığı çatı formları oluşturulmuştur (Kuban,1995, s. 245). Konutta \%33 eğimli kırma çatı tasarlanmıştır. Geleneksel ahşap yapım sistemli oturtma çatı olarak inşa edilmiştir. Ahşap çatı makasları, ahşap aşıklar ve mertekler kullanılmıştır (Şekil 5, Şekil 6). Çatı kaplama malzemesi olarak açıklı koyulu renk geçişli ve eskitilmiş -rustik- tarzda kendine özgü yüzey dokulu bir kiremit serisi tercih edilmiştir. Su geçişine engel olan su yalıtımlı ve dona karşı dayanıklı malzeme seçimine dikkat edilmiştir.

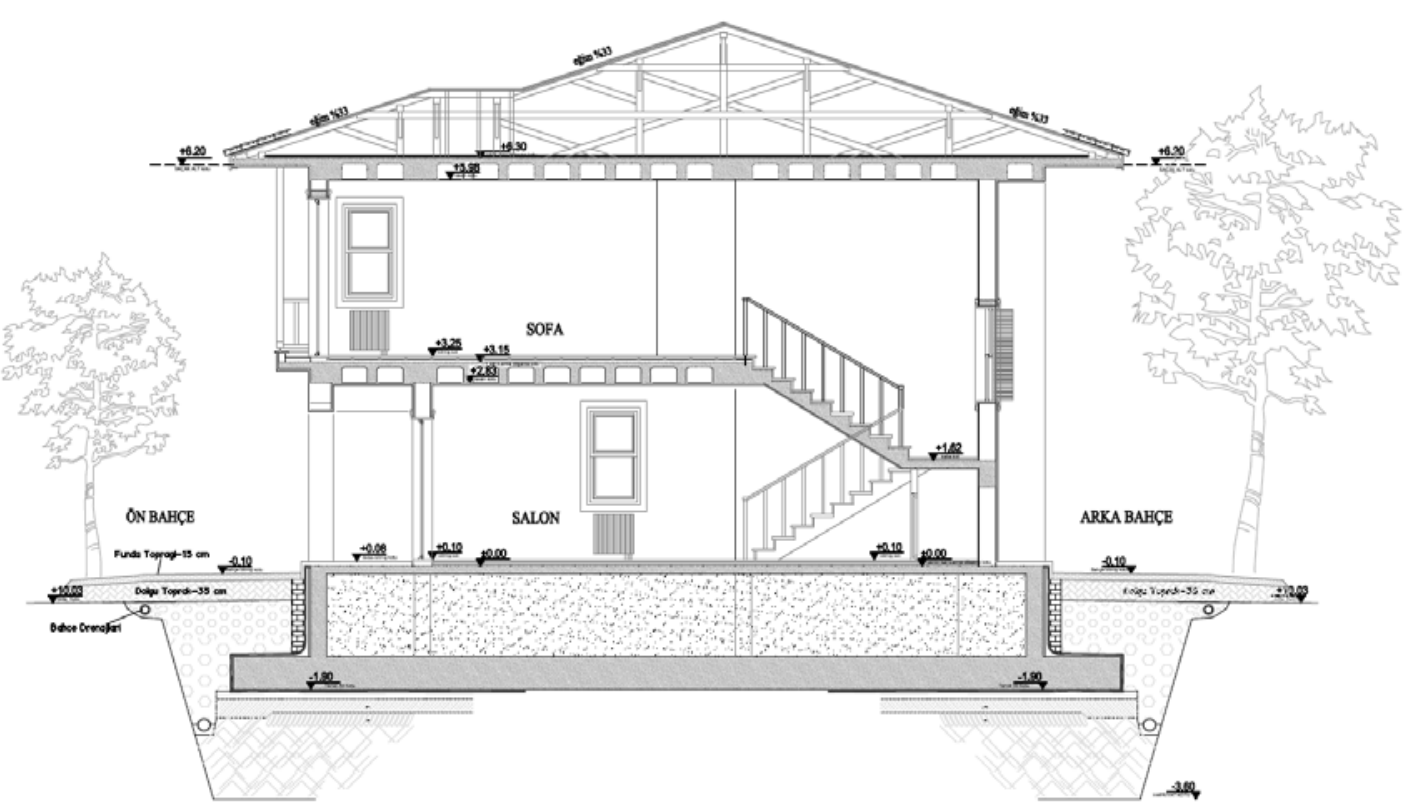

Şekil 5: A-A Kesiti (Çizen: Hülya Soydaş Çakır ve Burak Çakır) 


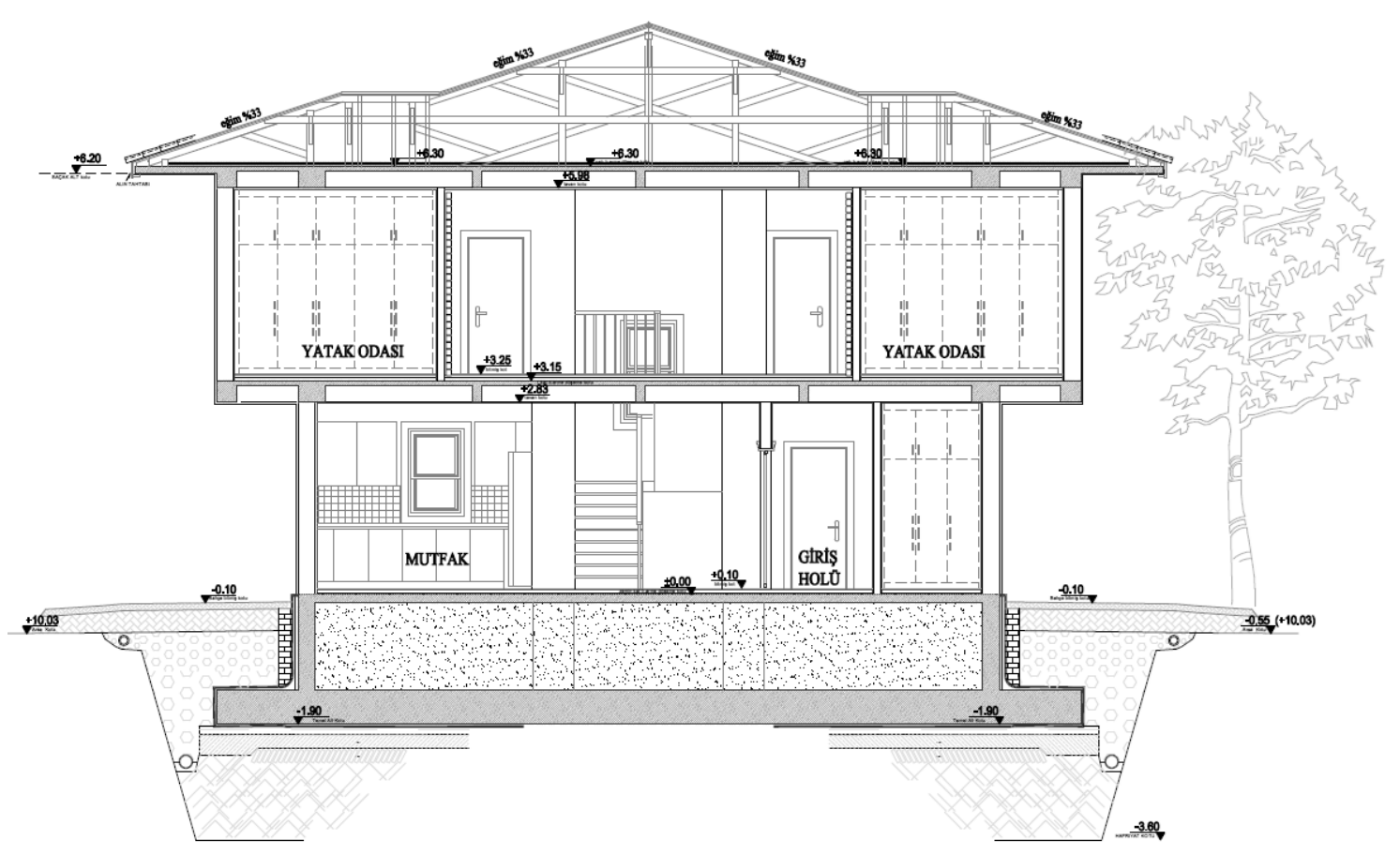

Şekil 6: B-B Kesiti (Çizen: Hülya Soydaş Çakır ve Burak Çakır)

Türk evi örnekleri belirli bir şablonun aynen uygulandığı yapı biçimleri olmamakla birlikte, bölgenin yaşam ve üretim biçimi, mevcut yapı malzemeleri ve yapım teknolojileri, topografya, arsa verisi ve konut sahibi ailenin sosyo ekonomik yapısı ile şekillenen tasarımlardır (Günay, 1998, s.66). Geleneksel mimari örnekler, iklim koşullarının etkisiyle kendilerine özgü teknik ve yöntemler geliştirmiştir. Yeni yapılarda veya yenilenen mevcut yapılarda uygulanacak çağdaş yapısal detayların fiziksel çevre değerlerin detaylı incelenmesinden sonra tanımlanması, mimari kültürün ve kimliğin korunmasına destek olacaktır (Arpacıoğlu, 2016, s.41). Özellikle ahşap ve doğal taş malzemenin yaygın olarak kullanıldığı konutta sıcak ve samimi mekanların oluşması sağlanmıştır. Malzeme uygulamalarında detaylara önem verilmiş ve tasarımın bütün olarak uyum içinde olmasına özen gösterilmiştir (Fotoğraf 13, Fotoğraf 14, Fotoğraf 15, Fotoğraf 16).

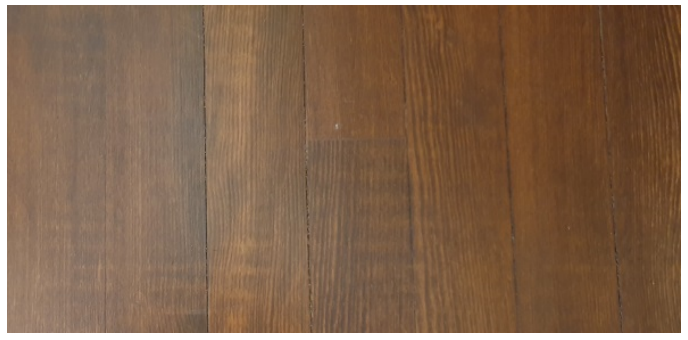

Fot. 13: Doğal ahşap zemin döşeme kaplaması (Hülya Soydaş Çakır, 2021)

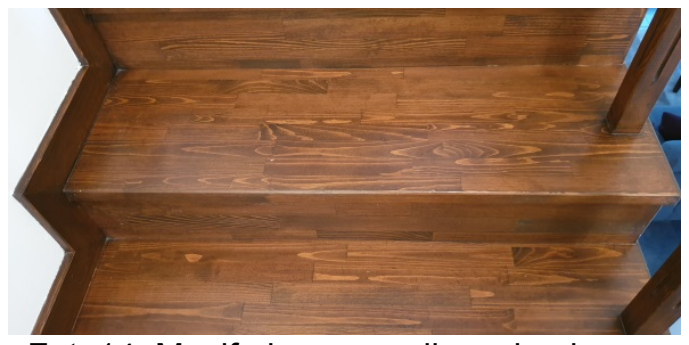

Fot. 14: Masif ahşap merdiven kaplaması (Hülya Soydaş Çakır, 2021) 


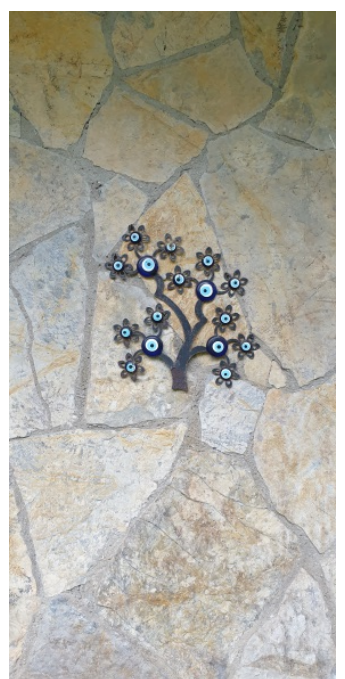

Fot. 15: Konut dış duvarı doğal taş kaplaması (Hülya Soydaş Çakır, 2021)

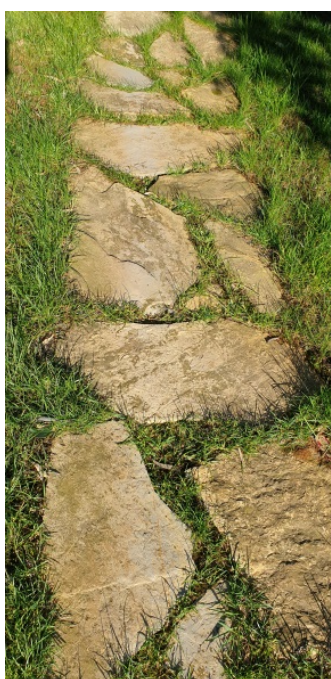

Fot. 16: Doğal taş bahçe yürüyüş yolu (Hülya Soydaş Çakır, 2021)

$\mathrm{Bu}$ örnek konut uygulamasında, geleneksel yaşam tarzının ve mimarinin çağdaş malzeme ve yapım teknikleri ile ele alındığı bahçe ile iç içe, korunaklı ve sade bir plan tasarımı tercih edilmiştir (Fotoğraf 17, Fotoğraf 18). Aile bireylerinin açık ve kapalı mekanları günün her saatinde amaçlarına uygun olarak kullanabilmelerine dikkat edilmiştir. Doğadan kopmadan, yeşil alanların katkısını öne çıkaracak biçimde akılcı ve sade çözümler geliştirilmiştir.

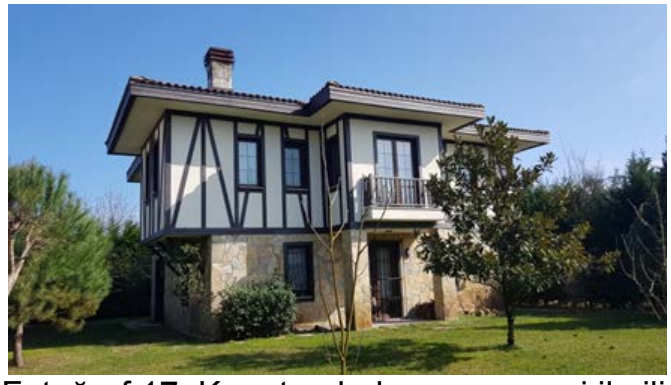

Fotoğraf 17: Konutun bahçe ve peyzaj ile ilişkisi (Hülya Soydaş Çakır, 2020)

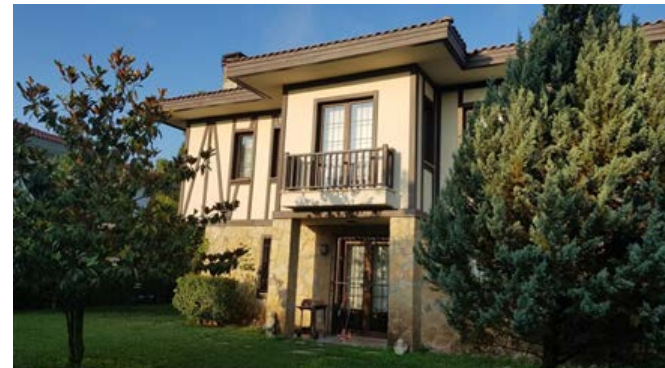

Fotoğraf 18: Konutun bahçe çıkış kapısı (Hülya Soydaş Çakır, 2020)

Konut arazisinin etrafında yetiştirilen ve doğal sınır oluşturan ağaçların katkısıyla kullanıcıların sakin ve huzurlu bir ortamda yaşam sürdürülebilmeleri sağlanmıştır. Konutun bahçe sınırları içinde güneşten ve gün ışığından en verimli şekilde yararlanılabilmektedir. Kışın bol güneş ışığı alan bahçenin mevsimsel kullanım süresi oldukça uzamaktadır. Yaz mevsiminde ise mevcutta korunan ve ilave olarak yetiştirilen ağaçların doğal gölgelerinden faydalanılmaktadır. Konut aile tarafından tüm mevsim şartlarında doğa ile ilişkisi kesintiye uğramadan kullanılabilmektedir.

\section{Değerlendirme ve Sonuç}

Konut tasarımları yüzyıllar boyunca insan intiyaçlarından, kültürlerden, sosyo-ekonomik gelişimlerden etkilenerek şekillenmeye devam etmektedir. Konut tasarımında, kullanıcının fiziksel ve ruhsal sağlığının korunması, çevresel değerler ile uyum, işlevsellik ve ekonomiklik aynı zamanda sürdürülebilirlik gibi fonksiyonların gözönüne 
alınması gerekmektedir. Bir konut tasarımı sadece kullanıcıları tarafından değil ait olduğu çevre ve diğer yaşayanlar tarafından da değerlendirilmektedir.

Bu çalışmada ele alınan konut tasarımı yer aldığı ilçe sınırları dahilinde çevre değerler ile uyum çabasında olan, kullanıcılarının yaşam biçimini ve taleplerini destekleyen, geleneksel yapım unsurlarını günümüz koşullarında ve tekniklerinde yorumlayan bir örnek olarak oluşturulmuştur. Sadelik, tutumluluk, esneklik, içten-dışa çözüm gibi geleneksel konutların şekillenmesinde etkili olan ilkelerin karşılanması hedeflenmiştir. Kullanıcı deneyimleri ve yorumları tasarım hedeflerinin gerçekleşmesinde önemli göstergeler haline gelmiştir. Konutun sadece yaşam alanı olarak değil üretme ve paylaşma mekanı olarak şekillendirilmesi dikkate alınmıştır. Aile bireylerinin, aile yakınlarının, konukların ve ziyaretçilerin hem açık hem kapalı mekanları verimli biçimde kullanarak birbirlerinin sınırlarına müdahele etmeden ortak paylaşımlar yapabilmelerine imkan sağlanmıştır. Geleneksel plan tiplerinin ve yaklaşımlarının yorumlandığı, mevcut intiyaçlara göre mekanların biçimlendirildiği tasarımda konutun doğa ve yakın çevredeki yapılar ile uyum içinde olmasına dikkat edilmiştir. Ahşap, taş, kiremit gibi doğal malzemelerin kullanımına özen gösterilerek özellikle konut sakinlerinin memnuniyet algılarında önemli rol alan yeşil alan kullanımına ağırlık verilmiştir. Konut, sahibi olan ailenin ve konukların yaşam kalitelerine olumlu katkılarda bulunmakta, çevre ile ilişkilerini koparmadan kullanılabilmektedir. Doğal ağaç sınırları içinde korunaklı ve özel bir yaşam alanı oluşturulurken konutun çevresi ile arasındaki geçirgenlik sürdürülmektedir. Tasarımda ön plana çıkarılan tüm canlılar ve çevre ile uyum anlayışının hayata geçirilmesi sağlanmaktadır.

Kullanıcılar tarafından ihtiyaç duyulan tüm mekanlar işlevsel olarak tasarlanırken aynı zamanda teknik ve estetik açıdan olumlu uygulamalarla gerçekleştirilmesi gerekmektedir. Konut tasarımının şekillenmesinde teknik zorunluluklar, çevresel referanslar, yasal düzenlemeler rol alırken, tasarımda ekonomik ve sosyal koşulların etkilerini de değerlendirmeye almak gerekir. Farklı iklimler, yerel şartlar hem tasarımı hem de teknik koşulları etkilemektedir. Özellikle bağımsız konut tasarımı, çevre ile olan ilişkilerin daha açık ve net gözlemlenmesi, kullanıcı tercihlerinin daha tanımlı olması açısından dikkat gerektirmektedir. Kullanıcıların bireysel alışkanlıkları, günlük rutinleri, sosyal yaşantıları konut intiyaçlarını şekillendiren önemli faktörlerdir. Tasarım kararlarında konut kullanıcılarının beklentilerinin karşılanması ve yaşam kalitelerinin artırıması hedeflenmektedir. Optimum mekan organizasyonlarının gerçekleştirilmesi, intiyaç duyulan fiziksel standartların sağlanması gerekir. Tasarımın bütününde işlevsel ve estetik performans düzeylerinin yüksek olması beklenir. Konutun türü, büyüklügü, yapı sisteminin, malzemelerin, mobilyaların seçimi kullanıcıların ekonomik durumu ve bütçesi ile yakından ilişkilidir. Aile için sosyal ve fiziksel mekanlar bütünü olan konut, içinde sürdürülen yaşamlar boyunca farklı zamanlarda farklı faaliyetler ile tecrübe edilecektir. Konutların artık temel barınma gereksiniminin ötesinde aile bireylerinin fiziksel, sosyal, psikolojik, estetik beklentilerine cevap verebilecek bir yapı biçimine dönüşmesiyle birlikte, geleneksel mimari tasarım ilkeleri; malzeme ve strüktür seçiminde, konutun çevre ve doğa ile olan ilişkisinde, toplum ve aile yaşam biçimlerindeki ilişkilerde önemli ipuçları sağlamaktadır. Geleneksel plan tiplerinin ve tasarım ilkelerinin değişen aile yapıları ve gelişen teknoloji ile birlikte yeniden yorumlanması, uygun koşullarda gerçekleştirilmesi tarihsel ve kültürel mimari anlayışın yaşatılmasında aynı zamanda gelecek kuşaklara aktarılmasında destek olmaktadır. 


\section{Kaynaklar}

Ahunbay, Z. (1996). Tarihi Çevre Koruma ve Restorasyon, İstanbul: YEM Yayın.

Akdemir, M. Z. ve Korkmaz, E. (2010). Geleneksel Konut Dokularında Malzemenin Çatı ve Cephe Kuruluşuna Etkileri: Batı Karadeniz Bölgesi Örneği. 5. Ulusal Çatı ve Cephe Sempozyumu (129-135 ss.). Dokuz Eylül Üniversitesi Mimarlık Fakültesi Tınaztepe Yerleşkesi, Buca, İzmir, 15-16 Nisan 2010.

Arpacıoğlu, Ü. (2016). Evaluation of the physical environment in Anatolian rural architecture. ITU A|Z, 13(3), 25-42.

Baydar, L. ve Gerçek, C. (1982). Sedad Hakkı Eldem: Büyük Konutlar. Ankara: Yaprak Kitabevi.

Bektaş, C. (2019). Türk Evi (6. Baskı). İstanbul: YEM Yayın.

Berköz, L. (2008). İstanbul'da korunaklı tek-aile konutları: Konut kalitesi ve kullanıcı memnuniyetinin belirlenmesi. ITÜ Dergisi Seri A: Mimarlık, Planlama, Tasarım, 7 (1), 110-124.

Cura, B. A. ve Eyüpgiller, K. K. (2019). Urban Conservation Proposal: The Case of Şile Balibey District. International Journal of Architecture \& Planning, 7(2), 352-384.

Eldem, S. H. (1954). Türk Evi Plan Tipleri. İstanbul: ITÜ Mimarlık Fakültesi, Pulhan Matbaası.

Ertek, T. A. ve Evren, E. N. (2004). Bir Coğrafi Mekan Analizi: Şile İlçesi. İstanbul: Güven Yayın.

Ertek, T. A., Kozak, R., Evren, E. N. (1998). Şile: Doğal Tarihi ve Kültürel Yapısı, Sosyo-Ekonomik Analizi ve Gelişme Stratejileri. İstanbul: Mataş Matbaacılık.

Hasol, D. (1993). Ansiklopedik Mimarlık Sözlüğü. İstanbul: Yapı-Endüstri Merkezi Yayınları.

Göktaş, A. (1992). Şile'de Tarihsel Araştırma ve Çevre Koruma Çalışmaları: Hamamdere ve Balibey Mahalleri. (Yayımlanmamış yüksek lisans tezi). Yıldız Teknik Üniversitesi Fen Bilimleri Enstitüsü, İstanbul.

Günay, R. (1998). Türk Ev Geleneği ve Safranbolu Evleri. İstanbul: Yapı-Endüstri Merkezi Yayınları.

Köse, A. (2005). Türkiye'de Geleneksel Kırsal Konut Planlarında Göçebe Türk Kültürü İzleri. Sosyal Bilimler Dergisi, 7(2), 158-191.

Kuban, D. (1992). Mimarlık Kavramları: Tarihsel Perspektif içinde Mimarlığın Kurumsal Sözlüğüne Giriş (4. Baskı). İstanbul: YEM Yayın.

Kuban, D. (1995). The Turkish Hayat House. İstanbul: Eren Yayıncılık.

Küçükerman, Ö. (1991). Kendi Mekanının Arayışı İçinde Türk Evi. İstanbul: Türkiye Turing ve Otomobil Kurumu. 
Özdoğan, M. (2016). İstanbul'un Tarihi Yarımada Dışı Coğrafyasında Göz Ardı Edilen Tarihöncesi Kültürler. Mimar.ist, 57, 18-22.

Salihoğlu, T. ve Türkoğlu, H. (2019). Konut Çevresi ve Kentsel Yaşam Kalitesi. Megaron, 14 (Ek Suppl.1), 203-217. https://dx.doi.org/10.5505/megaron.2018.06977

Sezer, Y. (2006). Şile ve Civarının (İstanbul) Flora ve Vejetasyonu. (Yayımlanmamış yüksek lisans tezi). Marmara Üniversitesi Fen Bilimleri Enstitüsü, İstanbul.

Şentürk, Ö. ve Biricik, A. S. (2016). Anadolu Feneri Karasu Arası Sahil Şeridi ve Yakın Çevresi Strüktür ve Rölyefinin Planlama Kriterlerine Etkileri. Marmara Coğrafya Dergisi, 33, 334-347.

Teker, T. (1992). Şile'de Tarihsel Araştırma ve Çevre Koruması. (Yayımlanmamış yüksek lisans tezi). Yıldız Üniversitesi Fen Bilimleri Enstitüsü, İstanbul.

Temir, Ş. R. (2010). Geçmişten Günümüze Şile ve Şile Bezi. Ankara: Kültür ve Turizm Bakanlığı Yayınları.

Uzun, T. ve Topal, Y. (2019). 1930-1940 Yılları Arası İstanbul ve Londra İki Büyük Kentin Mustakil Evlerin Karşılaştırmalı Değerlendirilmesi. Mimarlık, Planlama ve Tasarım Alanında Araştırma ve Değerlendirmeler içinde (5-34). Kaya, L. G. ve Abbasova, S. (Ed.), Ankara: Gece Akademi.

Yürekli, H. ve Yürekli, F. (2007). Türk Evi-Gözlemler-Yorumlar (2. Baskı), İstanbul: YEM Yayın.

\section{İnternet Kaynakları}

URL-1: MTA İstanbul İli Maden ve Enerji Kaynakları,

https://www.mta.gov.tr/v3.0/sayfalar/bilgimerkezi/maden potansiyel 2010/Istanbul Madenler.pdf Erişim tarihi: 27.01.2020, saat: 14.39

URL-2: Google Maps, https://www.google.com/maps/@41.1568501,29.568695,8415m/data=!3m1!1e3 Erişim tarihi: 10.04.2021, saat: 17.14 